https://doi.org/10.18485/unislav.2017.ch12

378.6: [811.161.3+821.161.3(497.11)“2006/2017“

\author{
СВЕТЛАНА ГОљАК* \\ Филолошки факултет Универзитета у Београду \\ Београд, Србија
}

\title{
ДЕСЕТ ГОДИНА СРПСКЕ БЕЛОРУСИСТИКЕ
}

\begin{abstract}
У раду је дат преглед развоја белорусистике на Филолошком факултету у Београду и доприноса различитих учесника у том процесу. Настава белоруског језика је у Београду покренута 2006. године. Издвајају се три основне фазе развоја током којих је предмет „белоруски језик” имао различит статус: 1) белоруски језик као факултативни предмет (2006-2009); 2) белоруски језик као изборни предмет (2009-2017); 3) белоруски језик као други словенски језик (од школске 2017/2018. године); такође се од 2017. године уводи настава белоруске књижевности.
\end{abstract}

Кључне речи: белоруски језик, белорусистика, славистика.

Настава белоруског језика у Србији је први пут покренута на Филолошком факултету у Београду 2006. године када је уз подршку руководства Факултета и Катедре за славистику, а пре свега академика П. Пипера, проф. П. Буњака и других професора, одржан факултативни курс „Белоруски језик и култура” за студенте-слависте. Управо с тим задатком руководство Филолошког факултета Белоруског државног универзитета у Минску упутило је тада у Београд наставника Катедре за словенску и теоријску лингвистику Светлану Гољак, аутора ових редова, тако да је нови курс представљао изузетан пример сарадње филолошких факултета и славистичких катедара у Београду и у Минску.

Желели бисмо да истакнемо да универзитетска сарадња Београда и Минска има дугу традицију и да је од пресудног значаја за њу управо настава језика. Изборни предмет „српски језик” на Филолошком факултету у Минску је покренут 1965. године, а први предавач је била Вера Лумбина. Године 1997. у Минску је отворена студијска група за српски језик и књижевност, уз подршку проф. А. Супруна, проф. И. Чароте, као и других наставника. Отварање групе је било прави одговор на изазове

*svetlanagoljak@yahoo.co.uk 
времена обележеног развојем младих славистика у новоформираним словенским државама. Увођење предмета „белоруски језик” у Београду је представљало реципроцитетну меру и сведочило о повећању интересовања за различите словенске језике и културе.

Правни оквири универзитетске сарадње у новије време су формирани 1996. године када је потписан споразум о сарадњи између двају главних универзитета. Међууниверзитетски споразум се од тада обнављао неколико пута. У циљу унапређења сарадње два филолошка факултета су 2005. године додатно потписала програм сарадње који се такође редовно обнавља. Програм предвиђа конкретне облике сарадње као што су гостовања професора, размена студената и постдипломаца, као и низ других заједничких наставних и научних активности. У складу са програмом, 2005. године је први пут организован студијски боравак групе од 20 студената руског језика на Филолошком факултету у Минску.

У развоју белорусистике на Филолошком факултету у Београду издвајају се три основне фазе током којих је предмет „белоруски језик” имао различит статус: 1) белоруски језик као факултативни предмет (2006-2009); 2) белоруски језик као изборни предмет на Филолошком факултету (2009-2017); 3) белоруски језик као други словенски језик (од школске 2017/2018. године).

У почетној фази учења белоруског језика наставни процес је био заснован искључиво на ентузијазму лектора и студената који су факултативни курс похађали у своје слободно време, без добијања бодова које носи редован предмет. Том првом курсу је претходило уводно предавање о историји и савременом стању белоруског језика које сам одржала у оквиру предмета „Увод у славистику”, уз сагласност и подршку предавача тог предмета у 2006. години, кандидата филолошких наука Вере Борисенко. Студенти прве године су током предавања активно постављали питања показавши огромно интересовање и доста скромно знање језичке ситуације у Белорусији, с обзиром да раније нису имали прилику да сазнају више о овој земљи, поред осталог и зашто у њој званично постоје два државна језика, руски и белоруски, колико се та два језика разликују, који је од њих сличнији српском језику итд. Након предавања је у року од 3 дана формирана група од 56 студената који су желели да слушају предмет „Белоруски језик и култура”, а курсу је такође присуствовало и неколико наставника са славистике.

Традиција предавања о белоруском језику и култури, у оквиру увода у славистику на првој години, настављена је свих наредних година, захваљујући подршци академика Пипера и нашој сарадњи са њим. На тај начин је студентима пружена прилика да прошире славистичке видике, да чују изворни белоруски и да се кроз директан контакт и разговор са лектором више заинтересују за белоруски језик. 
Настава у почетној фази развоја белорусистике се одвијала у складу са правилима и традицијама Катедре за славистику. Први курс „Белоруски језик и култура" је трајао 3 месеца. На завршни испит изашло je 30 полазника и сви су га успешно положили. Након тога једна група највећих ентузијаста 4 семестра је учила белоруски језик. Прве лекторке белоруког језика биле су С. Гољак и Љ. Циманович. Групу је чинило 10 студената руског језика. На личну молбу часовима су присуствовала и 2 студента са других факултета Универзитета у Београду.

Посебно треба истаћи диван гест подршке коју су српским студентима-ентузијастима пружили белоруски студенти. У жељи да подрже прве студенте белоруског језика у Србији и да им улепшају наставу, студенти српског језика у Минску и неколико студената белоруског језика, током неколико година почев од 2007, под мојим руководством су припремали текстове и задатке за учење белоруског језика. Основни део грађе су чинили хумористички текстови (оригинални текстови и студентски преводи са руског језика на белоруски), као и поезија, а многи задаци су засновани на језичким играма. Та збирка-читанка за почетни ниво белоруског као страног језика још чека објављивање, а веома је активно коришћена у настави.

Први студенти белоруског језика су учествовали у бројним културним манифестацијама посвећеним белоруској култури. Већи део прве групе белорусиста је ушао у састав хора „Слависта” и запевао „Купалинку", као и друге белоруске песме. Помажући младом хору да нађе праву интонацију и да пренесе дух народне песме у обликовању првог извођења познате „Купалинке” учествовали су чланови чувеног хора Андреја Тарасјева „Лучинушка” чији репертоар укључује и низ белоруских песама.

Студенти-белорусисти су радили и као волонтери на Београдском сајму књига где је 2006. године Белорусија први пут учествовала са посебним штандом. Волонтирање студената на сајму књига касније је постало добра традиција и део сарадње Факултета са Амбасадом Белорусије у Србији. Студенти су такође учествовали у изради српских титлова за фестивал у Позоришту „Славија” где је 2011. године приређено прво извођење драме на белоруском језику у Београду (гостовање Позоришта белоруске драматургије, драма С. Каваљова „Дневник песника”). Сви ти први кораци који су заједно чинили студенти и наставници, уметници и дипломате, сведоче о непроцењивом значају знања језика у процесу упознавања и зближавања култура.

За прве српске белорусисте у октобру 2009. године организован је студијски боравак на Филолошком факултету у Минску где су студенти усавршили знање белоруског језика захваљујући часовима доц. Татјане Рамзе, познатог стручњака за белоруски језик као страни. Долазак срп- 
ских белорусиста у Минск је изазвао велику пажњу широке јавности и пропраћен је у главним новинама. Такође, организоване су посете више музеја и других културних установа, уз пратњу новинара, као и интервјуи на Националној телевизији и првом каналу белоруског радија. На питање новинара зашто су изабрали да уче белоруски, студенти су давали најразличитије одговоре: „Допала ми се мелодија белоруског језика, звучи певљиво и нежно...” (Ана Грујић), „Желела сам да подржим Белорусе да не забораве белоруски језик” (Ивана Мрђа), „Заинтересовало нас је колико су слични српски и белоруски језик" (Наталија Николић и Оливера Пралица).

Нова фаза развоја српске белорусистике почела је школске 2009/2010. године добијањем статуса изборног предмета. Сачињен је и акредитован наставни програм који предвиђа двогодишњи, односно четворосеместрални курс белоруског језика П1-П4. Од тада све до 2017. године белоруски језик је завршило преко 70 студената филолошког факултета са различитих студијских група, а највише русиста и србиста. Током тог периода лектори белоруског језика били су С. Гољак, М. Супрунчук и А. Наумова.

Белоруски србисти, Микита Супрунчук и Ана Наумова, ученици најпознатијег белоруског стручњака за српску књижевност проф. Ивана Чароте, по доласку у Београд су наставили и пренели традицију српскобелоруских превода књижевних дела коју више деценија у Минску негује и развија проф. Иван Чарота. У Београду се школа превођења белоруске књижевности развија пре свега захваљујући изузетном доприносу проф. М. Сибиновића (Антологија 2012 и др.), као и радовима других стручњака.

Микита Супрунчук је још више заинтересовао београдске студенте за превођење књижевних дела. Тако је током 2013. године објављено неколико превода прича белоруског аутора Виктара Супрунчука које су заједно припремили Микита Супрунчук и Александра Ђукић, представник већ поменуте прве генерације белорусиста (Супрунчук 2013, 2014). М. Супрунчук и данас објављује своје преводе (Караткевич 2017).

Белорусисти следећих генерација су објавили више превода белоруских аутора на српски језик који су излазили и као посебне брошуре. У оквиру својеврсног преводилачког клуба који је одржан у априлу 2016. године захваљујући залагању лекторке Ане Наумове, студенти Валентина Бујила, Дајана Лазаревић, Растислав Марковић, Даниел Ристић и Доротеја Џодић превели су изабране песме и одломке из дела белоруских књижевника. Брошура са њиховим преводима је приређена поводом промоције књиге „Белоруси о Србији и Југославији” чији је састављач проф. Иван Чарота која је одржана у Народној скупштини 
Србије 24.10.2016. године. Том приликом је брошура уручена народним посланицима и високим званичницима Србије.

Превод поезије Максима Багдановича који је припремила студент Дајана Лазаревић је изашао као посебна брошура (Bagdanovič 2017). Дајана Лазаревић је као тему свог мастер рада 2017. године изабрала библиографију превода са српског на белоруски и белоруског на српски, сакупивши податке из српског COBISS система, електронских база Белорусије, као и из библиографија у радовима проф. Ивана Чароте (Чарота 2016 и др.).

Поред преводилачких активности, лектори су учествовали у организацији размене студената и факултетских манифестација. Студентске књижевно-уметничке вечери посвећене белоруском језику, књижевности и култури које је на Факултету организовала Ана Наумова, биле су изузетно посећене.

Дајући генералну оцену другој фази развоја српске белорусистике, треба рећи да се она одликује већом консолидацијом свих снага и заинтересованих учесника у том процесу. О томе сведоче и наведени примери заједничког преводилачког рада наставника, лектора и студената, објављивање тих превода уз подршку Амбасаде Белорусије у Србији, као и друге чињенице. Посебно бисмо желели да истакнемо тесну сарадњу у периоду 2011-2017. године Факултета и Амбасаде чији су представници, а пре свега амбасадор Владимир Чушев лично, били редовни гости Факултета пружајући подршку свим његовим научним и културним активностима. Са своје стране, студенти и лектори су дали свој допринос бројним манифестацијама организованим уз учешће Амбасаде. Треба поменути редовно волонтирање студената на Београдском сајму књига, за време посета званичника, представника културе и спорта, учешће уз рецитовање поезије и певање песама у промоцијама књига и другим манифестацијама као што су „Дани Белорусије на Вождовцу” 2016. године, „Дани Минска у Београду” 2017. године итд.

Још један важан фактор подршке српској белорусистици биле су активније посете еминентних белоруских филолога Београду. Проф. И. Чарота током протеклих година је у Београду одржао низ предавања како за студенте, тако и за ширу јавност („Белоруси о Србији, Срби о Белорусији”, Филолошки факултет, 21.10.2016; „Белоруско-српски односи као научни проблем", САНУ, 28.10.2015. и др.). Проф. И.Чарота је такође припремио програм курса „Српско-белоруске културне и књижевне везе” за мастер академске студије „Културе у дијалогу” на Филолошком факултету. Проф. Б. Норман је учествовао у свечаности Славистичког друштва Србије 25.10.2016. поводом Дана словенске писмености када је добио повељу почасног члана Друштва и након тога је одржао предавање о процесима синтаксичке компресије у словенским језицима. 
Академик А. Лукашанец и други белоруски научници током протеклих година су учествовали на више научних скупова у Београду преносећи српским колегама и своје искуство организације Међународног славистичког конгреса у Минску 2013. године. Као што је познато, следећи конгрес слависта ће бити одржан у Београду 2018. године.

Ректорат Универзитета у Београду и Филолошки факултет у октобру 2016. године је посетио ректор Белоруског државног универзитета у Минску, академик С. Абламејко. Приликом сусрета са белоруским ректором су одржане две презентације посвећене настави белоруског језика у Београду (С. Гољак, А. Наумова), а студенти су на белоруском језику испричали госту своје утиске о учењу језика.

Догађаји у Србији у домену образовања и културе изазивају искрено интересовање белоруске јавности. Тако, цело издање чувених белоруских новина „Књижевност и уметност” („Літаратура і мастацтва”) од 21.10.2016. године посвећено је Србији и културним везама Србије и Белорусије.

Консолидацијом снага и подршком свих учесника у процесу развоја белорусистике створена је база за приступање трећој фази наставе белорусистике на основу нових акредитованих наставних програма. Белоруски језик почев од школске 2017/2018. године може да се учи као други словенски језик у оквиру славистичких студија. Поред тога, уводи се предмет „Белоруска књижевност” (као друга словенска књижевост). Све то омогућује шире и озбиљније проучавање белоруског језика, књижевности и културе управо за студенте који су славистику изабрали као своје професионално опредељење. Контрастивна истраживања белоруског и српског језика нису развијена у довољној мери (в. Гољак 2010), зато је од значаја формирање младог кадра оспособљеног за научни рад.

Надамо се да ће нове генерације српских белорусиста бити искрено посвећене озбиљном научном и преводилачком раду, као и ширењу културних веза двеју земаља. Катедра за славистику Филолошког факултета у Београду развојем белорусистике заокружује број славистичких предмета који се овде изучавају, настојећи да и даље буде најзначајнији наставни и научни славистички центар у региону, па и шире у Европи.

\section{ЛИТЕРАТУРА}

Анйолойија белоруске ӣоезије / Приредио И. Чарота; превод са белоруског М. Сибиновић. Београд: Српска књижевна задруга, 2012. - 230 стр.

Гољак С. Контрастивна истраживања српског и белоруског језика у Белору-

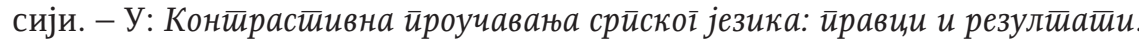
- Београд: САНУ, 2010. С. 101-106. 
Караткевич В. Плава-плава / Превео са белоруског М. Супрунчук. - У: Балкански књижевни ілласник / Приредио Д. Гојков, 2017, стр. 368-384. Доступно и на: https://issuu.com/balkanski.knjizevni.glasnik/docs/bkg 30-31-32

Супрунчук В. Анеља и Париз / Превели с руског М. Супрунчук и А. Ђукић. - У: Злайна ірреgа, Год. 13, бр. 139/140 (мај-јун 2013), стр. 21-24.

Супрунчук В. Ваља / Превела с белоруског А. Ђукић. - У: Књижевни майазин, Год. 14, бр. 150/153 (2013/2014), стр. 42-45. Доступно и на: http://www. skd.rs/magazin/magazinArhiva/150-153.pdf

Чарота И. Белорусија и Србија: йраїом узајамної уйознавања и деловања. - Шабац: Центар академске речи, 2016. - 290 стр.

Bogdanovič M. Venac / Prevela s beloruskog D. Lazarević. Beograd: Centar, 2017. -75 str.

Svetlana Golyak

10 YEARS OF BELARUSIAN STUDIES IN SERBIA

\section{Summary}

The article presents an overview of the development of Belarusian studies at the Faculty of Philology in Belgrade. The teaching of the Belarusian language started in 2006. There are three basic stages in which the subject "Belarusian language" had different status: 1) Belarusian as an facultative course (2006-2009); 2) Belarusian language as an elective course (2009-2017); 3) Belarusian as the second Slovenian language (from school year 2017/2018); the teaching of the Belarusian literature is starting from school year 2017/2018.

Key words: Belarusian language, Belarusian studies, slavistics. 